\title{
The Effect of Bank Loan Dependence on Management and Analyst Forecasts
}

\author{
SAORI NARA ${ }^{\dagger}$ \\ School of Commerce, \\ MEIJI UNIVERSITY
}

\author{
MIKIHARU NOMA ${ }^{\ddagger}$ \\ Graduate School of Business Administration, \\ HITOTSUBASHI UNIVERSITY
}

\begin{abstract}
This paper investigates whether and how dependence on bank loans affects management and analyst forecasts in Japan, where indirect finance has played an important role in financial arrangements for many years. We study 4,681 firm-year observations listed on the Japanese equity market from 2001 to 2011, and we show the following results. First, the dependence on bank loans increases management forecast errors. Second, the dependence on bank loans increases analyst forecast errors and dispersions but decreases analyst coverage. Third, dependence on bank loans decreases the value relevance of management and analyst forecasts. These empirical results show that disclosure and information environment are not good for firms that depend on bank loans. Furthermore, management and analyst forecasts are less incorporated in stock prices because investors rely on bank monitoring and do not utilize firms' public disclosures or other information, such as analyst forecasts, for those who depend on bank loan. Analyst coverage, analyst forecast accuracy, and forecast agreement are all lower for firms having long term-established relationships with banks in Japan. By contrast, our research contributes two things. First, we show that disclosure of firms that are dependent on bank loans are inadequate. More specifically, management forecasts of firms that are dependent on bank loans are less accurate. Second, we reveal
\end{abstract}

\footnotetext{
Acknowledgments:We appreciate the helpful comments of the discussants at the American Accounting Association Annual Meeting (2014). This work was supported by JSPS KAKENHI Grant Numbers 16K17217, 15K03764.

† Associate Professor, School of Commerce, Meiji University, Faculty Office Building 1125, Surugadai Campus, 1-1 Kanda-Surugadai, Chiyoda-ku, Tokyo 101-8301, Japan. Tel. +81-3-3296-2287, Fax. +81-3-3296-2287, E-mail: sarinara@meiji.ac.jp

₹ Professor, Graduate School of Business Administration, Hitotsubashi University, National Center of Sciences 2-1-2 Hitotsubashi, Chiyoda-ku, Tokyo 101-8439, Japan. Tel. +81-3-4212-3108, Fax. +81-3-4212-3020, E-mail: mnoma@hab.hit-u.ac.jp
}

Received March 5, 2018; accepted January 25, 2019; available online March 27, 2019 (Advance publication by J-Stage) DOI:10.11640/tjar.9.2019.01 
that management and analyst forecasts are less incorporated in stock prices in firms that are reliant on bank loans.

JEL Classification: M41; G21; G32

Keywords: Management Forecasts; Analyst Forecasts; Disclosure; Bank Loan; Bank Monitoring; Value Relevance

\section{Introduction}

This paper investigates whether and how the dependence on bank loans affects management and analyst forecasts in Japan, where indirect finance has played an important role in financial arrangements for many years. Jensen and Meckling (1976) argue that, once investment has taken place, managers use funds without inhibition, such that the interest of outside investors became dampened. When managers do not behave in ways desired by investors, those investors suffer losses in the form of agency costs. To minimize agency costs, therefore, monitoring and disclosures are necessary.

Monitoring is usually conducted by agents, such as banks, bond investors, and equity investors. Among these, only banks can access firms' private and public information. Therefore, Fama (1985) note that banks have information advantages over other investors. Additionally, Diamond (1984) state that bank monitoring is the most effective, because monitoring costs associated with other investor types can overlap, creating critical sub-optimality. This suggests that investors can rely on bank monitoring only if bank monitoring works well.

When bank monitoring is weak for some reason, or when firms increase funds from capital markets, public monitoring by investors (e.g., equity and bond holders) is required. Monitoring by investors is accomplished via firms' disclosures. Healy and Palepu (2001) imply that disclosures, such as management forecasts and financial reporting, have various benefits for firms. Such disclosures can reduce the cost of capital, improve liquidity, increase analyst coverage, and ameliorate information asymmetries. Thus, managers have an incentive to improve disclosures by enhancing voluntary disclosure protocols with mandatory disclosures, especially in firms dependent on external finances (Lang and Lundholm 1993, 1997; Healy et al. 1999).

Public disclosures, on the other hand, require more work. Thus, it becomes an additional cost for managers. Therefore, disclosure items and their frequency and quality vary temporally and cross-sectionally between firms. Generally, managers who raise funds from public markets diligently pursue disclosure objectives. By contrast, managers of firms that are dependent on bank loans and bank monitoring do not require public market funds. Thus, they have less incentive to disclose.

Additionally, some studies showed that information environments, such as analytical environments, are not enough for firms that depend on bank loans. Koga and Uchino (2012) investigate the role of firm analysts who have long-established relationships with banks, finding that analyst coverage, analyst forecast accuracy, and forecast agreement (i.e., analyst forecast dispersion) are all lower for firms that have long-term-established relationship with banks. Because long-term relationships suggest good evaluation by banks as banks monitor firms during the relationship. Therefore, investors do not require disclosure when they have less motivation to closely examine the firms. Additionally, the researchers mention that sharing private information 
with a few banks is less costly for firms compared to making full public disclosures.

We examine disclosures from firms that are dependent on bank loans, assuming that they typically do not provide sufficient disclosures for two reasons. First, investors do not require public information, because bank monitoring works well, and they rely on it. Second, the cost of public disclosure is relatively expensive compared to sharing private information with a few banks. When firms want to reduce disclosure, managers will reduce voluntary disclosures first. In Japan, among voluntary disclosures, management forecasts are time-consuming and costly for managers in terms of preparation and amendment. Therefore, management forecasts become the initial targets for the scrap heap when the reduction of disclosures is prioritized. Therefore, we focus on management forecasts especially its forecasting errors.

We also investigate the information environment more specifically the analysts, because we wish to test value relevance of both management and analyst forecasts. If investors do not require in-depth information about firms that depend on bank loans, then security analysts have no need to cover them. However, if analyst do not provide enough cover, their forecast errors and dispersions will increase. Furthermore, if investors neither require nor reference public information on bank-dependent firms and their analytical information, the information is less likely to be incorporated in stock prices.

For this paper, we study 4,681 firm-year observations, as listed on the Japanese equity market from 2001 to 2011. We conduct three analyses. First, we investigate the management forecast accuracy of firms that are dependent on bank loans. Next, we explore the relationship between the scale of bank loans and analyst forecast accuracy, analyst coverage, and analyst forecast dispersion. Finally, we test the value relevance of management and analyst forecasts to understand the extent to which this information is used in the stock market.

We focus on Japan for two reasons. First, indirect financing and the main-bank system both play a central role in Japan. The information environment, disclosure system, and firms' behaviors toward investors have changed over the past 15 years. However, many firms still depend on bank loans. Second, in Japan, more than $95 \%$ of listed firms disclosed annual management forecasts, as of FY2012, because securities exchanges strongly recommend the disclosure of management forecasts. Even firms that depend heavily on bank loans provide management forecasts, although arguments can be made to suggest that they would do so reluctantly and sparingly, compared to counterpart firms that are not beholden to banks in this way. Furthermore, we can apply management forecasts in the context of Ohlson's (2001) model to test value relevance. The institutional settings, vis-à-vis Japanese firms, are suitable for such an exercise, because such firms provide annual management forecasts, unlike firms in the United States.

Based on our three analyses, the following results are revealed. First, dependence on bank loans increases management forecast errors. Second, dependence on bank loans increases analyst forecast error and dispersion but has little to do with analyst coverage. Third, dependence on bank loans decreases the value relevance of management and analyst forecasts. These empirical results show that disclosure and information environment are not good for firms that depend on bank loans. Furthermore, management and analyst forecasts are less incorporated in stock prices, because investors do not refer to the information; they instead rely on bank monitoring for firms that depend on bank loans.

Koga and Uchino (2012) provide evidence that the information environments of firms with long-established relationship with banks are less rich in Japan. By contrast, our research provides two contributions. One is that we show that disclosure of firms dependent on bank loans are not 
adequate. Moreover, the management forecasts of firms that are dependent on bank loans are less accurate. The other is that value relevance of both management and analyst forecasts are low in such firms. Thus, management and analyst forecasts of firms that rely on bank monitoring are less incorporated in stock prices.

We also explain the management forecasting system in Japan (Section 2) before reviewing related literature and positing our hypotheses (Section 3). Our methodology and data are then delineated (Section 4), followed by the results of our empirical analysis (Section 5). Finally, we summarize our results and offer concluding remarks (Section 6).

\section{Management Forecast Systems in Japan}

Figure 1 shows the capital structure of firms in Japan and other key developed countries. The proportion of bank loans therein is highest in Japan, followed closely by Germany. However, Japanese firms reduced the scale of bank loans throughout the 2000s and increased the scale of external financing via the public market. Figure 2 shows the structure of debt and equity of Japanese firms. ${ }^{1}$ In FY2003, the proportion of bank loans (equity) was $51.0 \%$ (43.1\%). By FY2012, this pattern had inverted, and bank loans had declined to $42.8 \%$, compared to $51.8 \%$ for equity. Furthermore, from Figure 3, we find that the proportion of shares held by foreign investors who could not access private information increased over this period.

Starting around year 2000, managers became increasingly convinced of the need for constructive dialog with investors. Thus, disclosure systems began to change concomitantly with this awareness. For example, disclosures of business risks, analysis of financial conditions, corporate results, and corporate governance began in 2003. Quarterly disclosures commenced in 2004. Disclosure of managers' testimonies began in 2005, and corporate governance and board members' compensation disclosures were enhanced in 2010. Furthermore, prompt disclosure, voluntary disclosure, and relations with investors were improved.

Among these disclosures, reinforcement of management forecasts was especially important for managers and investors because this information affects investors' perspectives and stock prices. In Japan, listed companies commonly provide the next year's annual forecasts in a specific format called "Kessan Tanshin" ${ }^{2}$ when announcing financial predictions. This disclosure of management forecasts is a custom that started because of demand from a press club called the "Kabuto club." Subsequently, the Japanese Stock Exchanges Conference took over this custom; it now enforces management forecast announcements. Owing to this effort, the management forecasting system is widely diffused across Japan, taking a central role in disclosures.

In the management forecasts disclosure system, sales, recurring profit, and net income forecasts are disclosed about participating firms. Specific descriptions regarding forecasts and forecasts of operating profit have been required since 2006. Additionally, forecasted information is commonly disclosed in half-year periods and full business years. However, quarterly forecasts are not disclosed, unlike in the United States.

When firms do not disclose forecasts, they instead should give prior notice to the Tokyo Stock Exchange. Owing to this system, more than 95\% of Japanese listed companies announced

${ }^{1}$ We obtained these data from the Ministry of Finance, Japan. This is an annual survey assessing the real business activities of Japanese corporations. Methodological differences therein hinder comparisons with the data presented in Figure 1.

2 A financial statement that is disclosed quarterly and annually, like 10-Q and 10-K in the U.S. 
FIGURE 1. COMPARISON OF CAPITAL STRUCTURE OF FIRMS

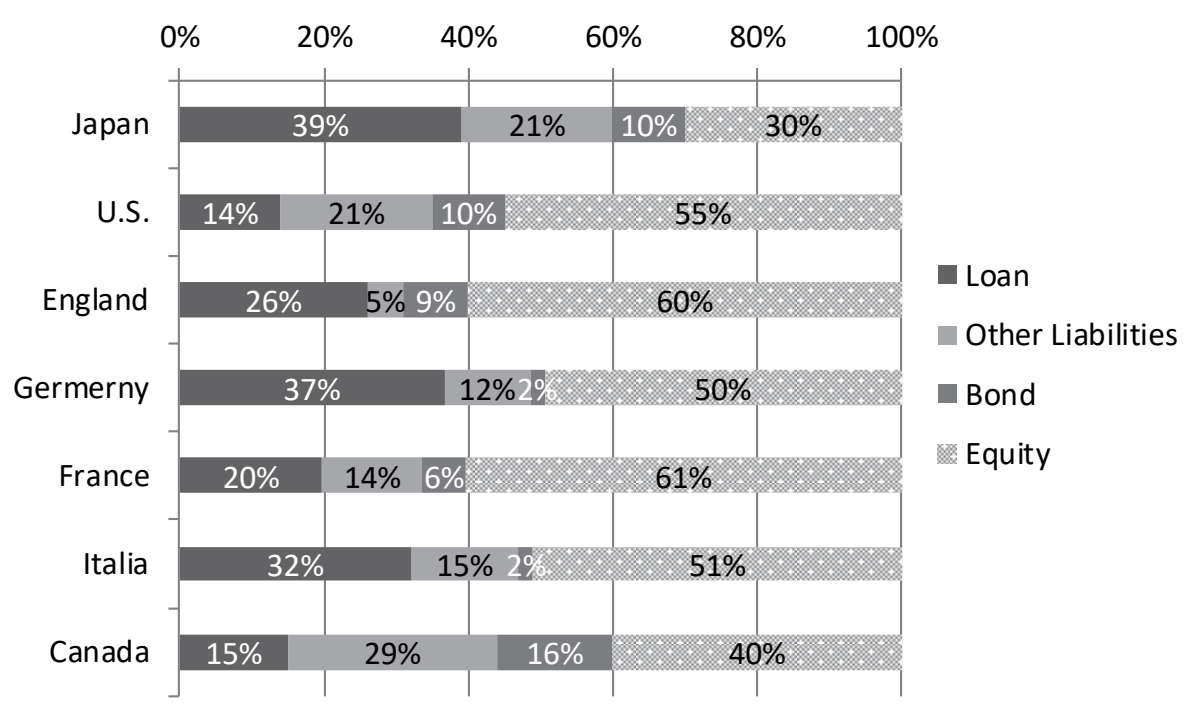

Reference: Bank of Japan. International comparison of flow of funds accounts (2003, P12).

FIGURE 2. CHANGES IN CAPITAL STRUCTURE FROM 2003 TO 2012 IN JAPAN

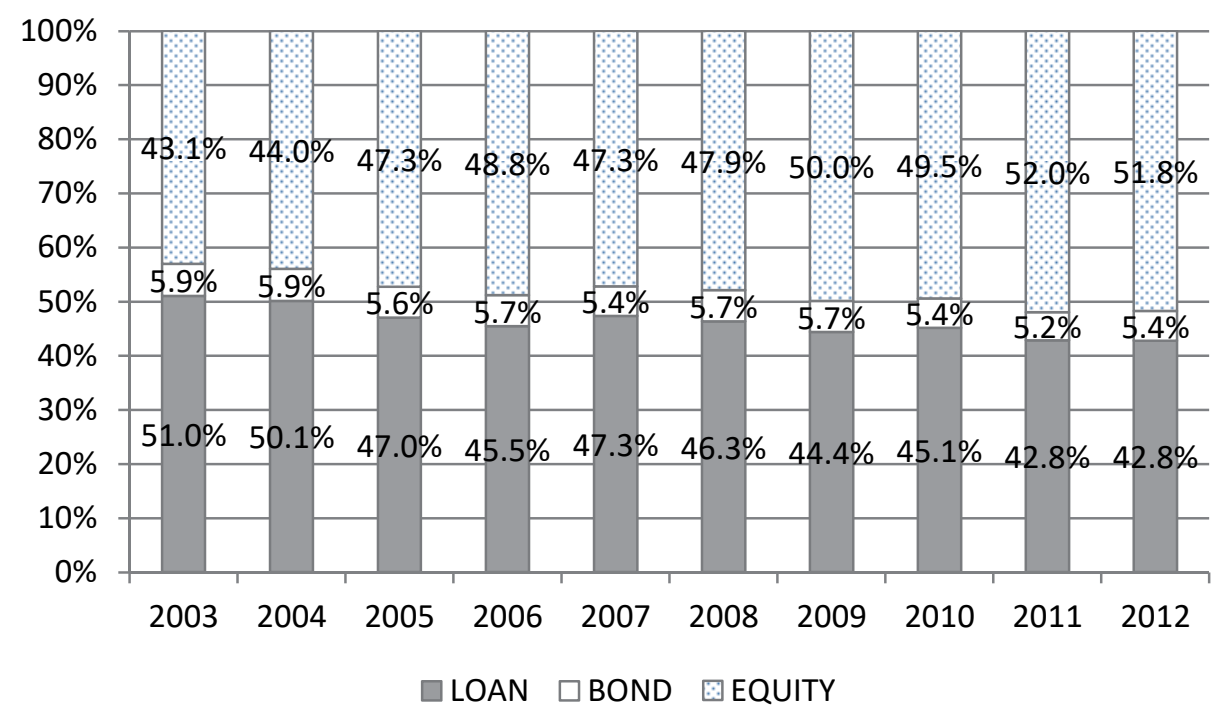

Reference: Ministry of Finance. Survey of corporations (Annually). 


\section{FIGURE 3. TRANSITION IN SHAREHOLDING RATIO BY SHAREHOLDER TYPE (ON A SHARE-NUMBER BASIS)}

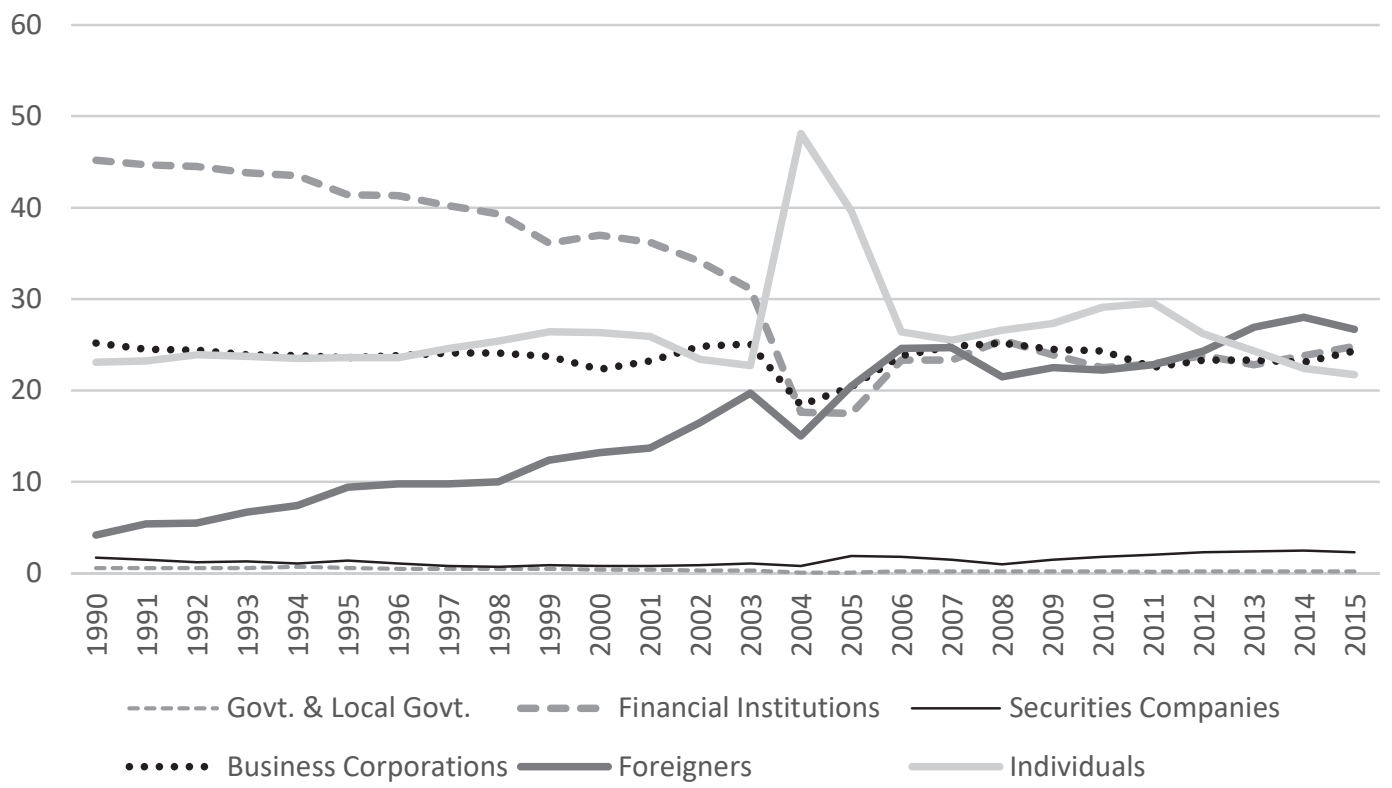

Reference: Japan Exchange Group. Share distribution survey.

management forecasts as of FY2012. Additionally, once firms disclose their forecasts, they are compelled to revise them as necessary. ${ }^{3}$ When firms revise their forecasts, new forecasts and rationale for amendments are registered by the listed companies via TD net. ${ }^{4}$ Thus, the management forecasts system in Japan treats disclosures as tantamount to mandatory. ${ }^{5}$

\section{Related Literature and Hypotheses}

\subsection{Related literature}

Monitoring is normally conducted by an agent (e.g., bank, bond investor, equity investor). However, disclosure requirements are heterogeneous across agent types. Firms provide two types of disclosure: public information that anyone can access and private information that limited parties, such as banks, can access. The difference is thus in terms of the right to access private information. Only banks can access all (public and private) information. This plausibly confers advantages.

3 For example, if published forecasts of sales change $\pm 10 \%$ or if published forecasts of operating profit, recurring profit, and net income change $\pm 30 \%$, firms must amend their original forecasts.

4 A timely disclosure network operated by the Tokyo Stock Exchange.

5 The management forecasts disclosure system is amended from 2012. For example, it was approved to make management forecasting private. However, the effect is limited and more than $95 \%$ of listed companies still announce management forecasts as of FY2012. Additionally, our study period is from 2001 to 2011, and our result is independent of the amendment. 
Leftwich (1983) discusses how banks have the substantive ability to gather and handle information compared to stock and bond investors. The corollary of this is that banks pay costs to obtain a comprehensive understanding of firms and to monitor them efficiently and effectively (Hoshi et al. 1990). The advantage of this for banks is that, by accessing firms' private information, they gain informational advantages over other investors. Diamond (1984) stated that bank monitoring is the most effective type of monitoring, whereas there are issues in terms of bonds and equity, because monitoring costs can overlap among investors and aggregate inter-investor costs, causing them to exceed accruable benefits. ${ }^{6}$ Additionally, Dass and Massa (2011) state that stronger relationships between banks and firms that inducing better monitoring would lead to better corporate borrower governance.

Prior research indicates that firms' attitudes toward disclosure change when bank monitoring is likely to also change in some way, perhaps via a corporate event (both the borrowers and bank). When bank monitoring seems to weaken, the firm's disclosure increases. Lo (2014) tests the disclosure of firms when a banking relationship is threatened by a decline in the bank's health, finding that borrowers increase their quality and informativeness of management forecasts after a decline of bank health. Chen and Vashishtha (2017) show that borrower disclosure increases when their bank engages in mergers and acquisitions (M\&A). Furthermore, they insist that the effect is stronger when the borrower relies heavily on the bank, and when the M\&A causes a large change in the bank's monitoring and borrowers' financing. Hence, disclosure of firms decreases when bank monitoring seems to strengthen. Vashishtha (2014) indicate that firms reduce disclosures after they violate covenants, because shareholders delegate the monitoring to banks.

Additionally, firms' attitudes regarding disclosure relate to the funding methods. Firms that will fund from public capital provide more disclosure. For example, Lang and Lundholm (1993) show that ratings of analysts increased in firms that issued securities in the current or future period. This meant that managers of those firms provided disclosure positively during the preparation of financial arrangements. Additionally, regarding firms that issue equity, Lang and Lundholm (1997) indicate that disclosure improves 6 months before the equity issue. These trends are confirmed in the case of issuing bonds. Healy et al. (1999) indicate that firms having experienced improved ratings from analysts are more likely to issue bonds. Moreover, regarding the relation between debt and disclosure, Eng and Mak (2003) find that ownership structure affect disclosure, and firms with lower debt had greater disclosure. They also conclude that disclosure is inversely related to debt (Singapore).

The information environment is also influenced by bank-loan dependence. Koga and Uchino (2012) show that the bank-firm relationship influences the information environments of many analysts. They find that analyst coverage, analyst forecast accuracy, and forecast agreement (i.e., analyst forecast dispersion) are all lower for firms having long-term-established relationship with banks. They insist that investors of firms that depend on bank loans do not require public information, because bank monitoring works well. Additionally, they state that sharing private information with a few banks is less costly for firms compared to making public disclosures. This is because firms must deliver public information to great number of investors through public disclosure.

${ }^{6}$ Petersen and Rajan (1994) show that the cost of loans increases according to the number of banks from which the firm borrows. 


\subsection{Hypotheses}

Based on the literature, investors seem to rely on bank monitoring when it works well. However, when bank monitoring changes, or, more specifically, when banking monitoring is likely to decline, disclosure of firms increase. Firms are thus inactive for disclosure when the effectiveness of bank monitoring is strong. Therefore, we research disclosures of firms that depend on bank loans. Additionally, as Koga and Uchino (2012) points out, demand for in-depth research of analyst is low for firms dependent on banks loans. Thus, we also investigate the information environment. Furthermore, to illuminate and explore these management and analyst forecasts, we test the value relevance of both forecasts, and we investigate information usage levels in equity markets.

We assume firms that rely on bank loans also rely on bank monitoring. Furthermore, we investigate their disclosure and information environments. Regarding disclosure, we investigate the accuracy of management forecasts. Additionally, for information environments, we focus on analysts, particularly in terms of forecast accuracy, coverage, and forecast dispersion.

\subsubsection{Disclosure: management forecasts}

There are two types of disclosures: mandatory and voluntary. When firms wish to reduce disclosure, they first target voluntary disclosures, because mandatory disclosure are required by law. Among voluntary disclosures, management forecasts are time-consuming and costly in terms of preparation and amendments. Thus, there is an inverse relationship between the quality of such forecasts and dependence of bank loan.

Hypothesis1-1: Dependence on bank loans increases management forecast errors.

\subsubsection{Information environment: analysts}

To test the information environment, we investigate analyst forecast error, analyst coverage, and analyst forecast dispersion. Koga and Uchino (2012) find that analyst coverage, analyst forecast accuracy, and forecast agreement (i.e., analyst forecast dispersion) are all lower for firms with long-term-established relationships with banks. Because investors do not require analyst information when bank monitoring works well, and because they can rely on bank monitoring in such firms, the following hypotheses apply.

Hypothesis2-1: Dependence on bank loans increases analyst forecast errors.

Hypothesis2-2: Dependence on bank loans decreases analyst coverage.

Hypothesis2-3: Dependence on bank loans increases analyst forecast dispersion.

\subsubsection{Value relevance of management and analyst forecasts}

If investors do not leverage management forecasts, the information is obviously less incorporated in the stock price. Thus, we surmise the value relevance of management forecasts of firms, dependent on bank loans, decreases.

Hypothesis3-1: Dependence on bank loans decreases the value relevance of management forecasts. 
A similar argument can be made about analyst forecasts. Thus, we surmise the value relevance of analyst forecasts of firms dependent on bank loans also decreases.

Hypothesis3-2: Dependence on bank loans decreases the value relevance of analyst forecasts.

\section{Methodology and Data}

We conduct three analyses. First, we investigate the relationship between the scale of bank loans and management forecast errors. Second, we investigate the relationship between the scale of bank loans and analyst forecast errors, analyst coverage, and dispersions in analyst forecasts. Third, we consider the relationship between the value relevance of these forecasts and the scale of bank loans.

To conduct these analyses, we calculate $L O A N$ in the first instance (Equation 1).

$$
\operatorname{LOAN}_{t}=\frac{\text { STborrow }_{t}+\text { CLTborrow }_{t}+\text { LTdebt }_{t}}{\text { STborrow }_{t}+\text { CLTborrow }_{t}+\text { LTdebt }_{t}+\text { TE }_{t}+\text { Cbond }_{t}+\text { CPCB }_{t}+\text { bond }_{t}+C B_{t}} .
$$

The denominator is the total amount of external financing, and the numerator is the total amount of bank loans, where STborrow is short-term borrowings, CLTborrow is current portion of long-term debt, LTdebt is long-term debt, $T E$ is total equity, Cbond is current portion of bonds, $C P C B$ is current portion of convertible bonds, bond is bonds, and $C B$ is convertible bonds. Koga and Uchino (2012) use total assets for the denominator. However, we use the sum of the external financing, because we want to clarify the impact of bank loans in external financing, except for the impact of reserves and so on.

Next, we define our dependent variables: management forecast error (MFERR), analyst forecast error $(A F E R R)$, analyst coverage $(A N)$, and the standard deviation of analyst forecasts (DISPAF). MFERR, AFERR, AN, and DISPAF are calculated as follows.

$$
\begin{aligned}
& M F E R R_{t}=\frac{\left|M F_{t}-A C T_{t}\right|}{M V E_{t-1}}, \\
& A F E R R_{t}=\frac{\left|A F_{t}-A C T_{t}\right|}{M V E_{t-1}},
\end{aligned}
$$

$A N=$ the number of analysts providing annual earnings forecasts, and

$$
D I S P A F_{t}=\frac{S D A F_{t}}{M V E_{t-1}},
$$

where $M F$ is the management forecasts of net income, $A C T$ is the actual earnings of net income, $A F$ is the analyst forecasts of net income ${ }^{7}, S D A F$ is the standard deviation of analyst net income forecasts, and $M V E$ is the market value of equity as of the end of the fiscal year (end of March). All remaining variables, except $M V E$, are set at the end of June each year. When $M F E R R$ and $A F E R R$ are large, the forecast accuracy is low. When DISPAF is high, consensus among analysts is lacking, which could be a function of increasing information asymmetry and uncertainty.

\footnotetext{
7 We use average of analyst forecast.
} 


\subsection{Disclosure: management forecasts}

To capture management forecast accuracy, we estimate a multiple regression model incorporating an array of plausible control variables (Equation 6).

$$
\begin{aligned}
\text { MFERR }_{t} & =\alpha_{0}+\alpha_{1} \text { LOAN }_{t-1}+\alpha_{2} \text { LOSS }_{t-1}+\alpha_{3} \text { SGROWTH }_{t-1}+\alpha_{4} \text { InMVE }_{t-1}+\alpha_{5} \text { OFFER }_{t-1} \\
& +\alpha_{6} \text { MFERR }_{t-1}+\alpha_{7} \text { MFERR }_{t-2}+\sum_{t=2}^{T} \gamma_{t} Y D_{t}+\sum_{j=2}^{J} \delta_{j} I D_{j}+\varepsilon_{t}
\end{aligned}
$$

$L O A N$ is the ratio of bank loans to external financing. If the dependence on bank loans increases management forecast errors, the coefficient of $L O A N$ will be positive.

$L O S S$ and $S G R O W T H$ are dummy variables for loss and sales growth over the previous year, respectively. Irani (2000) find that financially distressed firms tend to announce optimistic forecasts, whereas growing firms tend to announce pessimistic forecasts. Biased forecasts also decrease forecast accuracy. Thus, we predict that the coefficient of both variables will be positive. $\ln M V E$ is the natural logarithm of the market value of equity as of the end of previous year; it is a proxy variable for firm size. According to Jaggi (1980), the management forecast error of large firms tends to be small. We predict the coefficient will be negative. OFFER denotes income from seasonal offerings. Frankel et al. (1995) and Irani (2000) test forecast optimism of firms that are likely to access capital market. However, they did not find optimism in management forecasts. Using Japanese data, Ota (2006) show that seasonal public firms tend to announce pessimistic management forecasts, and biased forecasts decrease forecast accuracy. Thus, the coefficient should be positive. MFERR indicates management forecast error. Based on Williams (1996), the accuracy of management forecasts becomes an indicator of the believability of current management forecasts for analysts. This is not a direct result of management forecasts, but we believe previous forecast errors will affect current forecast errors. Thus, we invoke management forecasts from the past 2 years and predict that the coefficient will be positive. Additionally, we add year $(Y D)$ and industry (ID) dummies to control year and industry effects in an OLS regression.

\subsection{Information environment: analysts}

4.2.1. Accuracy of analyst forecasts

To investigate the effect of $L O A N$ on analyst forecasts, we estimate the following model.

$$
\begin{aligned}
\operatorname{AFERR}_{t} & =\alpha_{0}+\alpha_{1} \text { LOAN }_{t}+\alpha_{2} \operatorname{lnAN}_{t}+\alpha_{3} \text { EGROWTH }_{t}+\alpha_{4} \operatorname{lnTV}_{t}+\alpha_{5} \text { OFFER }_{t} \\
& +\alpha_{6} \operatorname{lnMVE} E_{t}+\sum_{t=2}^{T} \gamma_{t} Y D_{t}+\sum_{j=2}^{J} \delta_{j} I D_{j}+\varepsilon_{t} .
\end{aligned}
$$

$L O A N$ is the ratio of bank loans to external financing. If dependence on bank loans increases analyst forecast errors, then the coefficient of $L O A N$ will be positive.

$\ln A N$ is the natural logarithm of analysts following the firm as of the end of June. Brown (1997) indicates that analyst forecasts error tends to be small when firms have sufficient analyst coverage. We predict that the coefficient will be negative. EGROWTH represents earnings growth over the previous year. Cheong and Masum (2010) note that analysts invest resources in high-growth firms, where private demand for information is high, and that high-growth firms 
disclose additional information to show their growth potential. This information enables analysts to provide more-accurate information. Thus, the coefficient should be negative. $\ln T V$ is the natural logarithm of the trading volume. Hayes (1998) argues that analysts' research activities are affected by how much commission they can earn. High trading volume becomes an incentive for analysts to make optimistic forecasts. Thus, we predict that the coefficient will be positive. $O F F E R$ represents income from seasonal offerings. Firms that issue or sell stock have an incentive to issue optimistic forecasts (Ota 2006). Therefore, analyst forecasts are influenced by these forecasts, and the forecast errors will increase. Thus, we assume that the coefficient will be positive. $\ln M V E$ is the natural logarithm of the market value of equity as of the end of the fiscal year. Brown (1997) show that analyst forecasts of larger firms are more accurate. Thus, we predict the coefficient will also be negative. We again add year (YD) and industry (ID) dummies to control the year and industry effects for OLS regression.

\subsubsection{Analyst coverage}

For analyst coverage, we follow Bhushan (1989) and Rock et al. (2000) and estimate the following model.

$$
\begin{aligned}
\operatorname{lnAN}_{t} & =\alpha_{0}+\alpha_{1} \text { LOAN }_{t}+\alpha_{2} \text { FOR }_{t}+\alpha_{3} \text { PerFOR }_{t}+\alpha_{4} \text { RSQMKT }_{t}+\alpha_{5} L O B I_{t} \\
& +\alpha_{6} \text { Ret. } \text { Var }_{\cdot t}+\alpha_{7} \operatorname{lnMVE} E_{t}+\sum_{t=2}^{T} \gamma_{t} Y D_{t}+\sum_{j=2} \delta_{j} I D_{j}+\varepsilon_{t} .
\end{aligned}
$$

$L O A N$ is the ratio of bank loans to external financing. If analysts' coverage of firms with low dependence on bank loans tends to be small, the coefficient of $L O A N$ will be negative.

Regarding other independent variables, we follow Bhushan (1989). FOR and PerFOR are the number of foreign shareholders and percentage of ownership by foreign shareholders, respectively. Bhushan (1989) and Rock et al. (2000) indicate that the number of institutions holding shares in the firm and percentage of a firm's shares held them by increasing analyst coverage. We apply the number of foreign shareholders and the percentage of foreign shareholders owing to data restrictions. We suggest that if the needs from overseas investors are high, the demand for analysts' research increases. Thus, analysts' coverage increases. Therefore, we predict that both coefficients will be positive. RSQMKT is the $\mathrm{R}^{2}$ of the regression between a firm's return and the market's return. Bhushan (1989) and Rock et al. (2000) show that analyst coverage is positively associated with the relationship between a firm's return and market return. When this is low, marginal information acquisition costs increase and analysts avoid following such firms. We predict that the coefficients will be positive. LOBI shows the number of business domains. Bhushan (1989) and Rock et al. (2000) posit that the number of a firm's business domains affect the cost of information acquisition. When the number of those domains increases, information acquisition costs increase and analyst coverage decreases. Thus, the coefficient will be negative. Ret.Var. indicates the variance of the total return of the firm. Bhushan (1989) shows that need for analysts' research is an increasing function of the reliability of return. For firms where the return variability is high, private information is more valuable for predicting future returns. Because return variability leads to more analysts, we predict that the coefficient will be positive. $\ln M V E$ is the natural logarithm of the market value of equity as of the end of the fiscal year. Bhushan (1989) states that investors can generate larger profits from larger firms and that they can earn larger 
transaction fees from them. Therefore, the demand for research of larger firms increases, and its analyst coverage will increase. Thus, we expect the coefficient to be positive. We again add year $(Y D)$ and industry $(I D)$ dummies to control for year and industry effects in this OLS regression.

\subsubsection{Analyst forecast dispersion}

To investigate the effect of $L O A N$ on analyst forecast dispersion, we estimate the following model.

$$
\begin{aligned}
\text { DISPAF }_{t} & =\alpha_{0}+\alpha_{1} \text { LOAN }_{t}+\alpha_{2} \operatorname{lnAN} N_{t}+\alpha_{3} \text { EDISP }_{t}+\alpha_{4} \text { LOSS }_{t}+\alpha_{5} \text { EGROWTH }_{t-1} \\
& +\alpha_{6} \text { SGROWTH }_{t}+\alpha_{7} \operatorname{lnMVE} E_{t}+\alpha_{8} B M_{t}+\sum_{t=2}^{T} \gamma_{t} Y D_{t}+\sum_{j=2}^{J} \delta_{j} I D_{j}+\varepsilon_{t} .
\end{aligned}
$$

$L O A N$ is the ratio of bank loans to external financing. If the dependence on bank loans increases the analyst forecast dispersion, the coefficient of $L O A N$ will be positive.

$\ln A N$ is the natural logarithm of the number of analysts. When analyst coverage is small, information asymmetry increases. Thus, we predict that the coefficient will be negative. EDISP is the dispersion of net income over the past three years. When firms' earnings are volatile, it becomes difficult for analysts to forecast those earnings. Here, we predict that the coefficient will be positive. LOSS is a dummy variable for losses. Following Choi and Ziebart (2004), firms with losses tend to announce optimistic forecasts. Biased forecasts increase information symmetry and analyst forecast dispersion. Therefore, we predict that the coefficient will be positive. EGROWTH and SGROWTH are earnings growth and sales growth over the past year, respectively, indicating financial risk. McLaughlin et al. (1998) suggest that high-growth-rate firms tend to be associated with greater information asymmetries. Thus, the higher the growth rate, the larger the dispersion in analysts' forecasts. Therefore, we expect the coefficient to be positive. $\ln M V E$ is the natural logarithm of the market value of equity as of the end of the fiscal year. Bhushan (1989) and Rock et al. (2000) state that larger firms have superior information environments compared to smaller firms. In that case, information asymmetry decreases with analysts' forecast dispersion. Additionally, Lang and Lundholm (1996) show that analyst forecast dispersion is inversely related to firm size. Thus, the coefficient will be negative. $B M$ is the book-to-market ratio. This is a proxy variable for investment and growth opportunities, and it can be indicative of poor firm performance. Poor-performing firms tend to hesitate to disclose their performance, and information asymmetry increases. Thus, the coefficient will be positive. We again add year (YD) and industry (ID) dummies to control the year and industry effects for OLS regression.

All the above indicators are shown in Table 1.

\subsection{Value relevance of management and analyst forecast}

Ohlson (2001) state that firm value, including market value of equity and stock prices, is expressed by three factors: book value of equity, net income, and earnings forecasts. Additionally, Dechow et al. (1999) conduct an empirical analysis showing that analyst forecasts show value relevance by regressing with the book value of equity, net income, and earnings forecast (i.e., analyst forecasts).

Based on Ohlson (2001), showed that value relevance of management forecasts of firms dependent on bank loans tend to be low (Equation 10). 


\section{TABLE 1. DEFINITION OF VARIABLES}

Dependent variables

\begin{tabular}{|c|c|}
\hline Variables & Description \\
\hline \multirow[t]{2}{*}{ MFERR } & management forecast error \\
\hline & $\operatorname{MFERR}_{\mathrm{t}}=\operatorname{abs}\left(\mathrm{E}_{\mathrm{t}}-\mathrm{MF}_{\mathrm{t}}\right) / \mathrm{MVE}_{\mathrm{t}-1}$ \\
\hline AFERR & $\begin{array}{l}\text { analyst forecast error } \\
\mathrm{AFERR}_{\mathrm{t}}=\mathrm{abs}\left(\mathrm{E}_{\mathrm{t}}-\mathrm{AF}_{\mathrm{t}}\right) / \mathrm{MVE}_{\mathrm{t}-1}\end{array}$ \\
\hline $\ln A N$ & $\begin{array}{l}\text { logarithmic of the number of analyst at the end of June } \\
\ln \mathrm{AN}_{t}=\ln \left(\mathrm{AN}_{\mathrm{t}}\right)\end{array}$ \\
\hline \multirow[t]{2}{*}{ vDISPAF } & standard variation of analyst forecas \\
\hline & DISPAF $_{t}=$ standard variation of analyst forecast $t / \mathrm{MVE}_{\mathrm{t}-1}$ \\
\hline
\end{tabular}

Independent variables

\begin{tabular}{|c|c|}
\hline Variables & Description \\
\hline LOAN & $\begin{array}{l}\text { weight of bank loan to external financing } \\
\text { (Short-term borrowings }+ \text { Current portion of long-term debt }+ \text { Long-term debt)/ } \\
\text { (Short-term borrowings }+ \text { Current portion of long-term debt }+ \text { Long-term debt }+ \text { Total } \\
\text { equity }+ \text { Current portion of bond }+ \text { Current portion of convertible bond }+ \text { bond }+ \\
\text { convertible bond) }\end{array}$ \\
\hline LOSS & $\begin{array}{l}\text { loss dummy } \\
\text { when } \mathrm{E} \text { is negative } 1 \text {, otherwise } 0 \text {. Where } \mathrm{E} \text { is net income }\end{array}$ \\
\hline SGROWTH & $\begin{array}{l}\text { sales growth } \\
\text { SGROWTH }=\left(\mathrm{S}_{\left.\mathrm{t}-\mathrm{S}_{\mathrm{t}-1}\right) / \mathrm{MVE}_{\mathrm{t}-1} .} \text { Where } \mathrm{S} \text { is sales }\right.\end{array}$ \\
\hline $\operatorname{lnMVE}$ & $\begin{array}{l}\text { logarithmic of the market value of equity at the end of fiscal year (end of March) } \\
\ln \mathrm{VVE}=\log (\mathrm{MVE})\end{array}$ \\
\hline OFFER & $\begin{array}{l}\text { income from seasonal offering } \\
\text { OFFER }=\text { OFFER/MVE }\end{array}$ \\
\hline MFERR $_{\mathrm{t}-1}$ & $\begin{array}{l}\text { management forecast error of } \mathrm{t}-1 \\
\operatorname{MFERR}_{\mathrm{t}-1}=\operatorname{abs}\left(\mathrm{E}_{\mathrm{t}-1}-\mathrm{MF}_{\mathrm{t}-1}\right) / \mathrm{MVE}_{\mathrm{t}-2}\end{array}$ \\
\hline MFERR $_{\mathrm{t}-2}$ & $\begin{array}{l}\text { management forecast error of } \mathrm{t}-2 \\
\mathrm{MFERR}_{\mathrm{t}-2}=\operatorname{abs}\left(\mathrm{E}_{\mathrm{t}-2}-\mathrm{MF}_{\mathrm{t}-2}\right) / \mathrm{MVE}_{\mathrm{t}-3}\end{array}$ \\
\hline EGROWTH & $\begin{array}{l}\text { earnings growth } \\
\text { EGROWTH }=\left(E_{t}-E_{t-1}\right) / M_{t-1} \text {. Where } E \text { is net income }\end{array}$ \\
\hline $\operatorname{lnTV}$ & $\begin{array}{l}\text { logarithmic of the trading volume } \\
\ln T V=\log (\text { trading volume })\end{array}$ \\
\hline FOR & the number of foreign shareholders \\
\hline PerFOR & the percentage of ownership of foreign shareholders $(\%)$ \\
\hline RSQMKT & the $\mathrm{R}^{2}$ from the market model regression of a firm's return on the market return \\
\hline LOBI & number of business segment \\
\hline Ret.Var & estimated variance of a firm's daily stock return \\
\hline EDISP & $\begin{array}{l}\text { dispersion of net income of past three years } \\
\text { EDISP }=\text { EDISP/MVE }\end{array}$ \\
\hline EGROWTH2 & average earnings growth of past three years \\
\hline SGROWTH2 & average sales growth of past three years \\
\hline $\mathrm{BM}$ & $\begin{array}{l}\text { book to market ratio } \\
\mathrm{BM}=\mathrm{B} / \mathrm{MVE}\end{array}$ \\
\hline
\end{tabular}




$$
\begin{aligned}
M V E_{t}= & \alpha_{0}+\alpha_{1} B_{t-1}+\alpha_{2} E_{t-1}+\alpha_{3} M F_{t}+\alpha_{4}\left(M F_{t} \times L O A N_{t}\right) \\
& +\alpha_{5} L O A N_{t}+\sum_{t=2}^{T} \gamma_{t} Y D_{t}+\sum_{j=2}^{J} \delta_{j} I D_{j}+\varepsilon_{t} .
\end{aligned}
$$

$M V E$ is the market value of equity as of the end of the fiscal year. $B$ is the book value of equity, $E$ is net income, $M F$ is management forecasts regarding net income, and $L O A N$ is the ratio of bank loans to external financing. All variables except $L O A N$ and dummy variables are divided by the $M V E_{t-1}$ for the purpose of size adjustment. We predict that the coefficient of $M F$ will be positive if management forecast is value relevant. However, if the dependence on bank loans decreases the value relevance of management forecasts, the coefficient of $M F^{*} L O A N$ will be negative.

Similarly, we investigate the value relevance of analyst forecasts of firms that depend on bank loans. We thus show the model below (Equation 11).

$$
\begin{aligned}
M V E_{t}= & \alpha_{0}+\alpha_{1} B_{t-1}+\alpha_{2} E_{t-1}+\alpha_{3} A F_{t}+\alpha_{4}\left(A F_{t} \times L O A N_{t}\right) \\
& +\alpha_{5} L O A N_{t}+\sum_{t=2}^{T} \gamma_{t} Y D_{t}+\sum_{j=2}^{J} \delta_{j} I D_{j}+\varepsilon_{t}
\end{aligned}
$$

The definitions of $M V E, B, E$, and $L O A N$ are shown in Equation 10. $A F$ represents analyst forecasts regarding net income. All variables except $L O A N$ and dummy variables are divided by $M V E_{t-1}$ for the sake of size adjustment. We predict that the coefficient of $A F$ will be positive if analyst forecasts are value relevant. However, if dependence on bank loans decreases the value relevance of analyst forecasts, the coefficient of $A F^{*} L O A N$ will be negative.

We add year $(Y D)$ and industry $(I D)$ dummies to control year and industry effects for OLS regression. Furthermore, we add regressions estimated with robust standard errors clustered by firm and year. In this case, we regress the model without a year dummy. For OLS analysis, we provide two results, one including a year dummy and the other without.

\subsection{Descriptive statistics}

Our data are acquired from Astra Manager, provided by QUICK Corp., a financial service company of the Nikkei group in Japan. We use IFIS consensus of IFIS, a financial information service vendor in Japan for analyst forecast, analyst coverage, and analyst forecast dispersion, because QUICK does not provide analyst forecast dispersion. We study 4,681 firm-year observations, excluding financial sector entities (e.g., bank, securities, and insurance) listed on the Japanese equity market from 2001 to 2011. Data were removed where the settlement period was not $\mathrm{March}^{8}$ and where deviations from 12-month accounting occurred. Additionally, we use consolidated financial data above non-consolidated financial data. Furthermore, we limit the sample to that having analyst coverage for more than two, because we use analyst forecast dispersion in our analysis. ${ }^{9}$ June end forecast data for management and analyst forecasts is used,

8 In Japan, the accounting period of most firms is the end of March.

9 The samples shift to place a disproportionate emphasis on large firms. 
because management forecasts are announced from the end of April to mid-May in Japan. It takes about one month for analysts to revise forecasts. We removed upper and lower extreme values $(+/-0.1 \%)$ for each variable to mitigate outlier effects.

Table 2 provides descriptive statistics for the data. Panel A pertains to all variables used in our analysis. The minimum value of $L O A N$ is 0.000 , the median is 0.189 , the mean is $0.233^{10}$, and the maximum is 0.920 . From these figures, around $23 \%$ external financing is not provided through the public market. It is noteworthy that the maximum value of $L O A N$ is $92 \%$, indicating a very high dependency on bank loans. The mean of EGROWTH is negative, indicating that sample firms' performance is negative and that they struggle with poor performance. The mean of PerFOR is 18.620 , and the median is 17.030 . This indicates that the proportion of foreign investors is less than $20 \%$ during the period.

Panel $\mathrm{B}$ shows descriptive statistics per year. In terms of $L O A N$, both the mean and median in 2009 are high. Many firms braced for a rapid downturn in the economy and increased cash holdings because of the financial crisis. Prior to the crisis, the Japanese equity market was booming, and various firms raised funds from the equity market. Thus, $L O A N$ is relatively low compared to other years. This is consistent with the market timing hypothesis of Baker and Wurgler (2002), who noted that firms raise funds from equity market when their stock prices is high, but they chose internal financing or debt when the stock price is low. MFERR, AFERR, and $D I S P A F$ also substantively increase in 2008 during the financial crisis. This indicates that managers and analysts did not expect the financial crisis, and uncertainty increased over this year. Additionally, the median analyst coverage is consistently 5-6.

Panel $\mathrm{C}$ shows descriptive statistics per industry sector. We use the middle industry classification of Nikkei. Electric machinery, chemicals, machinery, and service sectors are substantial. Panel D shows the correlation of these indicators. Correlations among $\ln A N$, $\ln M V E$, and $F O R$ are high. Generally, large firms have significant analyst coverage and foreign investors. Furthermore, MFERR and AFERR are strongly correlated because management forecasts influence analyst forecasts, as indicated by Baginski and Hassell (1990) and Williams (1996).

Table 3 presents descriptive statistics by the weight of $L O A N$. We show the mean and median of MFERR, AFERR, AN, and DISPAF of five groups divided by the size of LOAN. Regarding mean and median $M F E R R$, the figures naively increase as the group number increases. The difference between group 1 and group 5 is significant at the $1 \%$ level. Therefore, management forecasts of the group where $L O A N$ is high (low) are less (more) accurate.

For $A F E R R$, both mean and median increase as the group number increases, and the difference between group 1 and 5 is significant at the $1 \%$ level. Similar to the foregoing, this indicates that analyst forecasts of the group where $L O A N$ is high (low) are less (more) accurate. For $A N$, both mean and median of group 5 are smaller than that of group 1 . However, this is not statistically significant. Additionally, we cannot observe a systematic trend in $A N$, because our sample is limited to firms in which analyst coverage is more than two. ${ }^{11}$ Both the mean and

${ }^{10}$ The weight of loans is lower compared to Figure 2, because our sample shifts toward larger firms. We use firms in which analyst coverage is more than two.

${ }^{11}$ When we include samples with more than one analyst coverage, the result is more robust, and analyst coverage of firms that depend on bank loans is smaller. 


\section{TABLE 2. DESCRIPTIVE STATISTICS AND BIVARIATE CORRELATIONS}

Panel A: Descriptive statistics

\begin{tabular}{lccccccc}
\hline \hline & $\mathrm{N}$ & Min. & 1st & Median & Mean & 3rd & Max. \\
\hline Dependent variables & & & & & & & \\
MFERR & 4,681 & 0.000 & 0.005 & 0.014 & 0.033 & 0.033 & 0.668 \\
AFERR & 4,681 & 0.000 & 0.005 & 0.013 & 0.033 & 0.033 & 0.632 \\
lnAN & 4,681 & 0.693 & 1.099 & 1.792 & 1.672 & 2.303 & 2.833 \\
vDISPAF & 4,681 & 0.000 & 0.002 & 0.004 & 0.006 & 0.007 & 0.146 \\
Variables of loan dependance & & & & & & \\
LOAN & 4,681 & 0.000 & 0.052 & 0.189 & 0.233 & 0.373 & 0.920 \\
Control variables & & & & & & & \\
LOSS & 4,681 & 0.000 & 0.000 & 0.000 & 0.024 & 0.000 & 1.000 \\
SGROWTH & 4,681 & -4.250 & -0.033 & 0.041 & 0.020 & 0.127 & 2.614 \\
lnMVE & 4,681 & 8.623 & 11.209 & 12.067 & 12.150 & 13.048 & 16.594 \\
OFFER & 4,681 & 0.000 & 0.000 & 0.000 & 0.004 & 0.000 & 0.337 \\
MFERR & 4,681 & 0.000 & 0.005 & 0.013 & 0.028 & 0.030 & 0.605 \\
MFERR & 4,681 & 0.000 & 0.005 & 0.012 & 0.029 & 0.029 & 0.597 \\
EGROWTH & 4,681 & -1.040 & -0.014 & 0.005 & -0.002 & 0.021 & 0.604 \\
lnTV & 4,681 & -5.854 & 1.141 & 2.456 & 2.303 & 3.646 & 7.374 \\
FOR & 4,681 & 4 & 104 & 205 & 258 & 353 & 1,619 \\
PerFOR & 4,681 & 0.610 & 9.860 & 17.030 & 18.620 & 25.660 & 68.540 \\
RSQMKT & 4,681 & 0.000 & 0.079 & 0.202 & 0.225 & 0.345 & 0.746 \\
LOBI & 4,681 & 1.000 & 2.000 & 3.000 & 3.225 & 4.000 & 13.000 \\
Ret.Var & 4,681 & 9.469 & 29.365 & 36.571 & 38.454 & 45.255 & 92.037 \\
EDISP & 4,681 & 0.020 & 7.670 & 38.690 & 671.400 & 208.030 & 66892.840 \\
EGROWTH2 & 4,681 & -0.594 & -0.012 & 0.001 & -0.004 & 0.011 & 0.244 \\
SGROWTH2 & 4,681 & -2.317 & -0.030 & 0.024 & 0.020 & 0.090 & 1.388 \\
BM & 4,681 & 0.082 & 0.515 & 0.739 & 0.808 & 1.020 & 2.792 \\
\hline
\end{tabular}

Panel B: Descriptive statistics by year

\begin{tabular}{cccccccccccc}
\hline \hline FY & N & \multicolumn{2}{c}{ LOAN } & \multicolumn{2}{c}{ MFERR } & \multicolumn{2}{c}{ AFERR } & \multicolumn{2}{c}{ AN } & \multicolumn{2}{c}{ DISPAF } \\
\hline & & mean & median & mean & median & mean & median & mean & median & mean & median \\
\hline 2001 & 384 & 0.254 & 0.209 & 0.047 & 0.026 & 0.046 & 0.025 & 5.922 & 5.000 & 0.006 & 0.003 \\
2002 & 386 & 0.248 & 0.204 & 0.028 & 0.014 & 0.027 & 0.014 & 6.832 & 6.000 & 0.006 & 0.004 \\
2003 & 406 & 0.251 & 0.191 & 0.025 & 0.012 & 0.024 & 0.012 & 6.379 & 5.500 & 0.007 & 0.005 \\
2004 & 428 & 0.240 & 0.190 & 0.019 & 0.010 & 0.017 & 0.009 & 6.505 & 5.000 & 0.004 & 0.003 \\
2005 & 424 & 0.227 & 0.177 & 0.021 & 0.011 & 0.021 & 0.010 & 6.394 & 5.000 & 0.004 & 0.003 \\
2006 & 468 & 0.216 & 0.170 & 0.014 & 0.007 & 0.013 & 0.007 & 6.466 & 5.000 & 0.003 & 0.002 \\
2007 & 495 & 0.212 & 0.162 & 0.020 & 0.009 & 0.020 & 0.009 & 6.624 & 5.000 & 0.004 & 0.003 \\
2008 & 485 & 0.215 & 0.174 & 0.086 & 0.049 & 0.087 & 0.053 & 6.849 & 6.000 & 0.006 & 0.004 \\
2009 & 418 & 0.253 & 0.219 & 0.042 & 0.019 & 0.041 & 0.021 & 6.725 & 6.000 & 0.013 & 0.007 \\
2010 & 411 & 0.235 & 0.201 & 0.025 & 0.013 & 0.024 & 0.012 & 6.908 & 6.000 & 0.007 & 0.005 \\
2011 & 376 & 0.222 & 0.180 & 0.035 & 0.015 & 0.035 & 0.015 & 6.625 & 6.000 & 0.008 & 0.005 \\
\hline & & & & & & & & & & (continued on next page)
\end{tabular}


TABLE 2. (continued)

Panel C: Descriptive statistics by industry

\begin{tabular}{lrlr}
\hline \hline Industry & Num of Obs. & Industry & Num of Obs. \\
\hline Fishery & 16 & Transportation Equipment & 5 \\
Mining & 8 & Precision Instruments & 124 \\
Construction & 215 & Other Manufacturing & 141 \\
Foods & 200 & Trading Companies & 212 \\
Textiles\&Apparel & 109 & Retail & 59 \\
Pulp \& Paper & 58 & Other Financial Services & 60 \\
Chemicals & 470 & Real Estate & 118 \\
Pharmaceuticals & 199 & Railway\&Bus & 71 \\
Petroleum & 27 & Land Transport & 80 \\
Rubber & 33 & Marine Transport & 32 \\
Glass\&Ceramics & 89 & Air Transport & 13 \\
Steel & 105 & Warehousing & 43 \\
Nonferrous Metals & 172 & Communications & 91 \\
Machinery & 454 & Electric Power & 90 \\
Electric Machinery & 744 & Gas & 32 \\
Automobiles \& Auto parts & 248 & Services & 335 \\
Shipbuilding & 28 & & \\
\hline
\end{tabular}

Note: This classification is the Nikkei Middle Industry Classification.

(continued on next page)

median DISPAF increase as the group number increases, and the difference between group 1 and 5 is significant at the $1 \%$ level. This result indicates that analyst forecast dispersion of the group where $L O A N$ is high is larger than the group where $L O A N$ is low. 


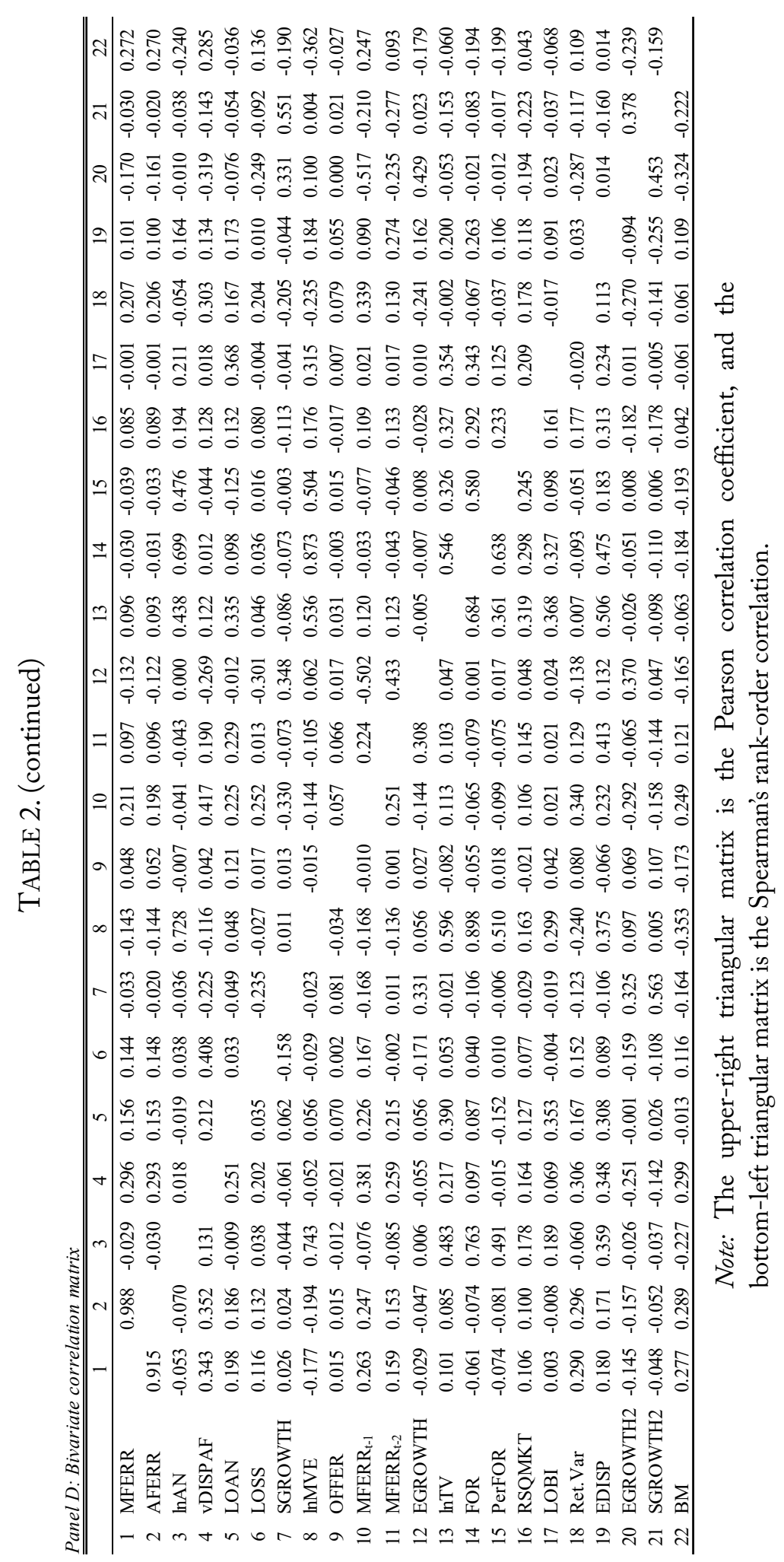


TABLE 3. DEsCRIPTIVE STATISTICS BY THE SIZE OF LOAN

\begin{tabular}{|c|c|c|c|c|c|c|c|c|c|}
\hline & & low & $\leftarrow$ & LOAN & $\rightarrow$ & high & & fference & \\
\hline & & 1 & 2 & 3 & 4 & 5 & $1-5$ & statistic & \\
\hline MFERR & Mean & 0.020 & 0.025 & 0.036 & 0.036 & 0.048 & -0.028 & -10.204 & **** \\
\hline & Median & 0.009 & 0.012 & 0.014 & 0.016 & 0.021 & -0.012 & -12.367 & *** \\
\hline AFERR & Mean & 0.020 & 0.025 & 0.035 & 0.035 & 0.048 & -0.028 & -10.038 & **** \\
\hline & Median & 0.009 & 0.012 & 0.013 & 0.015 & 0.021 & -0.012 & -11.498 & *** \\
\hline AN & Mean & 6.760 & 6.388 & 6.610 & 6.639 & 6.464 & 0.296 & 1.534 & \\
\hline & Median & 6.000 & 5.000 & 5.000 & 6.000 & 5.000 & 1.000 & 1.282 & \\
\hline DISPAF & Mean & 0.004 & 0.005 & 0.006 & 0.007 & 0.009 & -0.005 & -11.316 & **** \\
\hline & Median & 0.003 & 0.003 & 0.004 & 0.004 & 0.006 & -0.003 & -14.468 & **** \\
\hline $\mathrm{Nu}$ & bs. & 930 & 937 & 934 & 937 & 943 & & & \\
\hline
\end{tabular}

Note: The sample includes 4,681 firm-year observations that were listed on the Japanese equity market from 2001 to 2011 . We show the management forecast error (MFERR), the analyst forecast error $(M F E R R)$, the number of analysts $(A N)$, and the standard deviation of analyst forecast (DISPAF). Samples are divided into five portfolios by $L O A N$ size. $L O A N$ is calculated as follows.

$$
\operatorname{LOAN}_{t}=\frac{\text { STborrow }_{t}+\text { CLTborrow }_{t}+\text { LTdebt }_{t}}{\text { STborrow }_{t}+\text { CLTborrow }_{t}+\text { LTdebt }_{t}+T E_{t}+\text { Cbond }_{t}+C P C B_{t}+\text { bond }_{t}+C B_{t}},
$$

where STborrow represents short-term borrowings, CLTborrow is the current portion of long-term debt, LTdebt is the long-term debt, $T E$ is the total equity, Cbond is the current portion of bonds, $C P C B$ is the current portion of convertible bonds, bond is bond, and $C B$ is the convertible bond. $M F E R R, A F E R R, A N$, and DISPAF are calculated as follows.

$$
\begin{aligned}
& M F E R R_{t}=\frac{a b s\left(M F_{t}-A C T_{t}\right)}{M V E_{t-1}}, \\
& A F E R R_{t}=\frac{a b s\left(A F_{t}-A C T_{t}\right)}{M V E_{t-1}}, \\
& \mathrm{AN} \quad=\text { the number of analysts providing an annual earnings forecast, } \\
& \operatorname{DISPAF}_{t}=\frac{S D A F_{t}}{M V E_{t-1}},
\end{aligned}
$$

where $M F$ is the management forecast regarding net income, $A C T$ represents actual earnings regarding net income, $A F$ is the analyst forecast, $S D A F$ is the standard deviation of analyst forecast, and $M V E$ is the market value of equity as of the end of the fiscal year. Management forecast, analyst forecast, and the number of analysts are as of June of each year. ${ }^{* * *}$ indicates significance at the $1 \%$ level. 


\section{Results}

\subsection{Disclosure: Management forecasts}

Table 4 presents the results of the regression with $L O A N$ regarding disclosure. In this analysis, we show the results of the clustered-standard error regression with to OLS analysis. For OLS analysis, we provide two results. One is the result that includes the year dummy. The other is the result that does not include the year dummy. When we focus on the result of management forecasts $(M F E R R)$, the coefficient of $L O A N$ is positive and is statistically significant for every equation. This suggests that dependence on bank loans increases management forecast errors. After including other variables that are conceivable determinants of our dependent variables, we confirm the robustness of the foregoing five portfolio analyses.

Three control variables are statistically significant. The coefficient of LOSS is predicted to be positive, and the coefficients of $\ln M V E$ and $M F E R R_{t-1}$ are negative and positive, respectively. These results are consistent with our expectations and the extant literature.

\subsection{Information environment: analysts}

Table 5 presents the results of the regression with $L O A N$ regarding analysts. When we focus on the results of analyst forecast error (panel A), the coefficient of $L O A N$ is positive and significant. This result indicates that dependence on bank loans increases analyst forecast error. This is consistent with our hypothesis and previous analyses. The coefficient of $\ln A N$ is positive in contrast to our prediction because our sample is limited to firms in which analyst coverage is more than two (Table 3). Additionally, EGROWTH is negative. The coefficients of $\ln T V$ and InMVE are positive and negative, respectively. These results are consistent with previous research.

In the analysis of analyst coverage (Panel $\mathrm{B}$ ), the coefficient of $L O A N$ is negative but insignificant in OLS analysis with year dummy and the clustered-standard error regression. This may also relate to our sample selection, as we mentioned above. PerFOR, Ret.Var., and $\operatorname{lnMVE}$ are predicted to be positive and statistically significant for every equation. These results are consistent with our expectations and the results of Bhushan (1998) and Rock et al. (2000).

In terms of analyst forecasts dispersion (Panel C), the coefficient of $L O A N$ is positive and significant, indicating that dependence on bank loans increases the dispersion of analyst forecasts. The results are consistent with our prediction and the previous portfolio analysis results. Analyst forecast dispersion is used as a proxy variable for information asymmetry and future uncertainty (Barron and Stuerke 1998; Richardson 2000). Therefore, we can say information asymmetry and uncertainty increases in firms that depend on bank loans. Seven of the remaining eight independent variables are significant. The coefficient of $\ln A N$ is positive compared to our prediction. This could be a function of sample selection bias. As we mentioned before, we limited our study to firms that have an analyst coverage more than two. We think that analysts of firms with enough coverage do not delegate to other analysts. Thus, various forecasts are made. Furthermore, the coefficient of $l n M V E$ is negative. Additionally, the coefficients of EDISP, LOSS, and $B M$ are positive and significant. The coefficient of EGROWTH is negative and significant. 
TABLE 4. REgRESSION RESUlTS: DisCLOSURE

\begin{tabular}{|c|c|c|c|c|c|c|c|c|c|}
\hline & \multicolumn{9}{|c|}{ MFERR } \\
\hline & \multicolumn{3}{|c|}{ [1] OLS analysis } & \multicolumn{3}{|c|}{ [2] OLS analysis } & \multicolumn{3}{|c|}{$\begin{array}{l}\text { [3] clustered-standard } \\
\text { error regression }\end{array}$} \\
\hline & Estimate & $\mathrm{t}$ value & & Estimate & $\mathrm{t}$ value & & Estimate & $\mathrm{t}$ value & \\
\hline (Intercept) & 0.115 & 13.425 & *** & 0.113 & 11.574 & *** & 0.113 & 3.470 & *** \\
\hline LOAN & 0.039 & 8.708 & $* * *$ & 0.042 & 7.639 & $* * *$ & 0.042 & 4.450 & *** \\
\hline LOSS & 0.038 & 7.236 & $* * *$ & 0.040 & 4.537 & $* * *$ & 0.040 & 6.330 & *** \\
\hline SGROWTH & -0.001 & -0.494 & & 0.006 & 1.431 & & 0.006 & 0.600 & \\
\hline $\operatorname{lnMVE}$ & -0.005 & -8.389 & $* * *$ & -0.006 & -8.852 & $* * *$ & -0.006 & -3.760 & *** \\
\hline OFFER & 0.054 & 1.499 & & 0.047 & 0.685 & & 0.047 & 0.760 & \\
\hline MFERR $_{\mathrm{t}-1}$ & 0.150 & 7.791 & $* * *$ & 0.134 & 4.344 & $* * *$ & 0.134 & 3.440 & *** \\
\hline MFERR $_{\mathrm{t}-2}$ & 0.025 & 1.432 & & -0.014 & -0.691 & & -0.014 & -0.290 & \\
\hline year dummy & & Yes & & & No & & & NA & \\
\hline industry dummy & & Yes & & & Yes & & & Yes & \\
\hline Adj. $\mathrm{R}^{2}$ & 0.2 & & & 0.12 & & & 0.1 & & \\
\hline $\mathrm{R}^{2}$ & 0.2 & & & 0.12 & & & 0.1 & & \\
\hline
\end{tabular}

Note: Table 4 shows the results of the regression analysis of Equation (6). The sample includes 4,681 firm-year observations that were listed on the Japanese equity market from 2001 to 2011.

$$
\begin{gathered}
\text { MFERR }_{t}=\alpha_{0}+\alpha_{1} \text { LOAN }_{t-1}+\alpha_{2} \text { LOSS }_{t-1}+\alpha_{3} \text { SGROWTH }_{t-1}+\alpha_{4} \operatorname{lnMVE}_{t-1}+\alpha_{5} \text { OFFER }_{t-1} \\
+\alpha_{6} \text { MFERR }_{t-1}+\alpha_{7} \text { MFERR }_{t-2}+\sum_{t=2}^{T} \gamma_{t} Y D_{t}+\sum_{j=2}^{J} \delta_{j} I D_{j}+\varepsilon_{t}
\end{gathered}
$$

$L O A N$ is the weight of bank loan to external financing, LOSS is the loss dummy (when net income is negative, it is 1 ; otherwise, it is 0$), S G R O W T H$ is sales growth, InMVE is the logarithm of the market value of equity as of the end of the fiscal year, OFFER is income from seasonal offering, MFERR is the management forecast error, $Y D$ is the year dummy, ID is the industry dummy. [1] is the result of OLS analysis applying White's standard error. [2] is the result of OLS without year dummy analysis applying White's standard error. [3] is the result of a the clustered-standard error regression using standard errors clustered at the firm and year level. ${ }^{* * *}$ indicates significance at the $1 \%$ level. 


\section{TABLE 5. REGRESSION RESULTS: ANALYSTS}

Panel A: Analyst forcast error

\section{AFERR}

\begin{tabular}{|c|c|c|c|c|c|c|c|c|c|}
\hline & \multicolumn{3}{|c|}{ [1] OLS analysis } & \multicolumn{3}{|c|}{ [2] OLS analysis } & \multicolumn{3}{|c|}{$\begin{array}{l}\text { [3] clustered-standard } \\
\text { error regression }\end{array}$} \\
\hline & Estimate & $\mathrm{t}$ value & & Estimate & $\mathrm{t}$ value & & Estimate & $\mathrm{t}$ value & \\
\hline (Intercept) & 0.197 & 15.040 & *** & 0.200 & 14.654 & $* * *$ & 0.200 & 3.490 & $* * *$ \\
\hline LOAN & 0.036 & 6.810 & $* * *$ & 0.032 & 5.613 & $* * *$ & 0.032 & 3.580 & $* * *$ \\
\hline $\ln \mathrm{AN}$ & 0.010 & 5.488 & $* * *$ & 0.011 & 5.781 & $* * *$ & 0.011 & 2.190 & ** \\
\hline EGROWTH & -0.059 & -3.899 & $* * *$ & -0.060 & -4.342 & $* * *$ & -0.060 & -4.170 & *** \\
\hline $\ln \mathrm{TV}$ & 0.004 & 6.503 & *** & 0.005 & 7.682 & *** & 0.005 & 2.280 & ** \\
\hline OFFER & 0.075 & 1.180 & & 0.069 & 0.956 & & 0.069 & 1.110 & \\
\hline $\operatorname{lnMVE}$ & -0.014 & -11.693 & $* * *$ & -0.016 & -12.384 & $* * *$ & -0.016 & -3.220 & $* * *$ \\
\hline year dummy & & Yes & & & No & & & NA & \\
\hline industry dummy & & Yes & & & Yes & & & Yes & \\
\hline Adj. $\mathrm{R}^{2}$ & & 0.241 & & & 0.131 & & & 0.131 & \\
\hline $\mathrm{R}^{2}$ & & 0.249 & & & 0.138 & & & 0.138 & \\
\hline
\end{tabular}

Panel B: Analyst coverage

$\ln \mathrm{AN}$

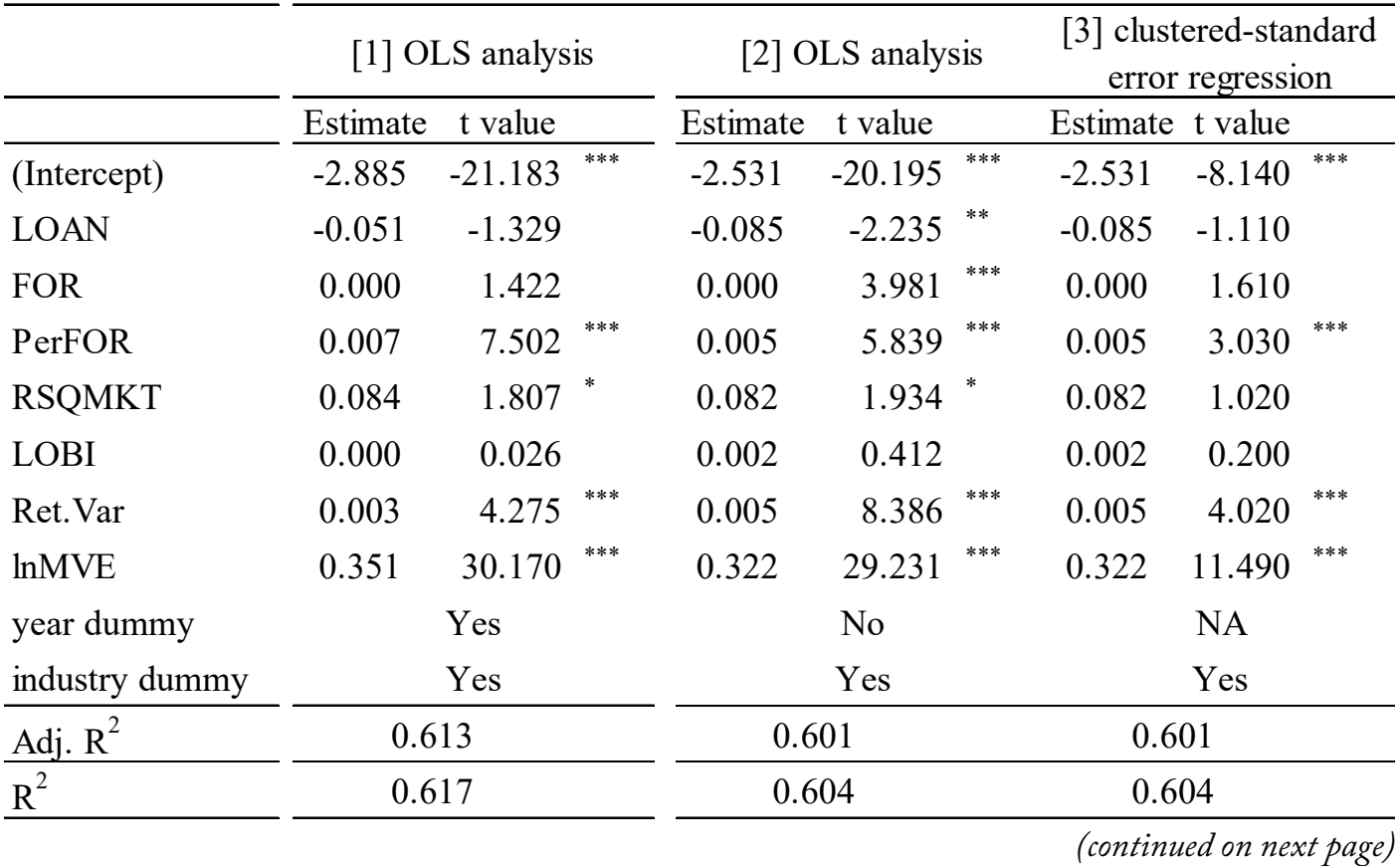


TABLE 5. (continued)

Panel C: Analyst forecast dispersion

\begin{tabular}{|c|c|c|c|c|c|c|c|c|c|}
\hline & \multicolumn{9}{|c|}{ DISPAF } \\
\hline & \multicolumn{3}{|c|}{ [1] OLS analysis } & \multicolumn{3}{|c|}{ [2] OLS analysis } & \multicolumn{3}{|c|}{$\begin{array}{l}\text { [3] clustered-standard } \\
\text { error regression }\end{array}$} \\
\hline & Estimate & $\mathrm{t}$ value & & Estimate & $\mathrm{t}$ value & & Estimate & $\mathrm{t}$ value & \\
\hline (Intercept) & 0.014 & 9.569 & $* * *$ & 0.013 & 9.584 & $* * *$ & 0.013 & 5.800 & $* * *$ \\
\hline LOAN & 0.008 & 13.471 & $* * *$ & 0.008 & 10.616 & $* * *$ & 0.008 & 6.050 & *** \\
\hline $\ln \mathrm{AN}$ & 0.002 & 7.904 & $* * *$ & 0.002 & 9.317 & $* * *$ & 0.002 & 6.430 & $* * *$ \\
\hline EDISP & 0.000 & 6.825 & $* * *$ & 0.000 & 3.907 & $* * *$ & 0.000 & 2.480 & ** \\
\hline LOSS & 0.017 & 24.462 & $* * *$ & 0.018 & 7.883 & $* * *$ & 0.018 & 7.540 & $* * *$ \\
\hline EGROWTH & -0.028 & -9.599 & $* * *$ & -0.032 & -6.019 & $* * *$ & -0.032 & -2.010 & ** \\
\hline SGROWTH & -0.001 & -1.716 & $*$ & -0.001 & -1.172 & & -0.001 & -0.940 & \\
\hline $\operatorname{lnMVE}$ & -0.001 & -9.305 & $* * *$ & -0.001 & -9.840 & $* * *$ & -0.001 & -5.660 & *** \\
\hline BM & 0.003 & 9.417 & $* * *$ & 0.004 & 8.723 & $* * *$ & 0.004 & 7.780 & $* * *$ \\
\hline year dummy & \multicolumn{3}{|c|}{ Yes } & \multicolumn{3}{|c|}{ No } & \multicolumn{3}{|c|}{ NA } \\
\hline industry dummy & \multicolumn{3}{|c|}{ Yes } & \multicolumn{3}{|c|}{ Yes } & \multicolumn{3}{|c|}{ Yes } \\
\hline Adj. $\mathrm{R}^{2}$ & \multicolumn{3}{|c|}{0.373} & \multicolumn{3}{|c|}{0.364} & \multicolumn{3}{|c|}{0.364} \\
\hline $\mathrm{R}^{2}$ & \multicolumn{3}{|c|}{0.380} & \multicolumn{3}{|c|}{0.370} & \multicolumn{3}{|c|}{0.370} \\
\hline
\end{tabular}

Note: Table 5 shows the results of regression analysis of equations (7), (8), and (9). The sample includes 4,681 firm-year observations that were listed on the Japanese equity market from 2001 to 2011 .

$$
\begin{aligned}
& \text { AFERR }_{t}=\alpha_{0}+\alpha_{1} \operatorname{LOAN}_{t}+\alpha_{2} \operatorname{lnAN}_{t}+\alpha_{3} \text { EGROWTH }_{t}+\alpha_{4} \operatorname{lnTV}_{t}+\alpha_{5} \text { OFFER }_{t}+\alpha_{6} \ln M V E_{t} \\
& +\sum_{t=2}^{T} \gamma_{t} Y D_{t}+\sum_{j=2}^{J} \delta_{j} I D_{j}+\varepsilon_{t} \\
& \operatorname{lnAN}_{t}=\alpha_{0}+\alpha_{1} \text { LOAN }_{t}+\alpha_{2} \text { FOR }_{t}+\alpha_{3} \text { PerFOR }_{t}+\alpha_{4} \text { RSQMKT }_{t}+\alpha_{5} \text { LOBI }_{t}+\alpha_{6}{\text { Ret } . \text { Var }_{\cdot}{ }_{t}} \\
& +\alpha_{7} l n M V E_{t}+\sum_{t=2}^{T} \gamma_{t} Y D_{t}+\sum_{j=2}^{J} \delta_{j} I D_{j}+\varepsilon_{t} \\
& D I S P A F_{t}=\alpha_{0}+\alpha_{1} L_{O A N}+\alpha_{2} \operatorname{lnAN}_{t}+\alpha_{3} E_{D I S P_{t}}+\alpha_{4} \text { LOSS }_{t}+\alpha_{5} E G R O W T H 2_{t-1} \\
& +\alpha_{6} \text { SGROWTH } 2_{t}+\alpha_{7} \operatorname{lnMVE} E_{t}+\alpha_{8} B M_{t}+\sum_{t=2}^{T} \gamma_{t} Y D_{t}+\sum_{j=2}^{J} \delta_{j} I D_{j}+\varepsilon_{t}
\end{aligned}
$$

$L O A N$ is the weight of bank loan to external financing, $M F E R R$ is the management forecast error, $\ln A N$ is the logarithm of the number of analysts as of the end of June, EDISP is the dispersion of net income of the past three years, LOSS is the loss dummy, EGROWTH2 is the average earnings growth of the past 3 years, SGROWTH2 is the average sales growth of the past three years, InMVE is the logarithm of the market value of equity as of the end of the fiscal year, $B M$ is the book-to-market ratio, $\ln T V$ is the logarithm of the trading volume, OFFER is income from seasonal offering, FOR is the number of foreign shareholders, PerFOR is the percentage of ownership of foreign shareholders (\%), RSQMKT is the $\mathrm{R}^{2}$ from the market model regression of 
a firm's return on the market return for year t. $L O B I$ is the number of business segments, Ret.Var. is the estimated variance of a firm's daily return, EDISP is the dispersion of net income of the past three years, LOSS is the loss dummy (when net income is negative, it is 1 ; otherwise, it is 0 ), $B M$ is the book-to-market ratio, $Y D$ is the year dummy, $I D$ is the industry dummy. [1] is the result of OLS analysis applying White's standard error. [2] is the result of OLS without year dummy analysis applying White's standard error. [3]is the result of the clustered-standard error regression using standard errors clustered at the firm and year level. *****, and * indicate statistical significance at the $1 \%, 5 \%$ and $10 \%$ levels, respectively.

\subsection{Value relevance of management and analyst forecasts}

Panel A of Table 6 provides descriptive statistics of variables, which we apply to value relevance analyses. Panel B provides correlations, and panels $\mathrm{C}$ and $\mathrm{D}$ provide regression results. When we focus on panel $\mathrm{B}$, there is a strong correlation between management forecasts and analyst forecasts. Baginski and Hussell (1990) and Williams (1996) state that management forecasts influence analyst forecasts. Additionally, correlations between $M F^{*} L O A N$ and $M F$ and between $A F^{*} L O A N$ and $A F$ are high.

Panel $\mathrm{C}$ delineates the results of regression analysis on management forecasts. When we focus on $M F^{*} L O A N$, coefficient values are negative and statistically significant. Thus, it would appear that the dependence of bank loans decreases the value relevance of management forecasts. The result is consistent with our hypothesis. Additionally, management forecasts of firms that depend on bank loan are less accurate, and the forecast is not informative to investors. This might be one of the reasons that management forecasts of firms that depend largely on bank loans are less incorporated into the market value of equity.

With respect to other variables, the coefficient of $M F$ is positive and significant. This indicates that management forecasts have value relevance. Nara and Noma (2012) test the value relevance of management and analyst forecasts in Japan, indicating the value relevance of both forecasts. Our results are consistent with their findings. Additionally, the coefficient of $B$ is positive and significant. Furthermore, the coefficient of $E$ is negative and significant. This does not match intuition. However, Dechow et al. (1999) state that the coefficient is negative.

Panel D provides regression results on analyst forecasts. When we focus on $A F^{*} L O A N$, all coefficients are negative and statistically significant. From this analysis, the dependence on bank loans decreases the value relevance of analyst forecasts. Additionally, the dispersion of analyst forecasts for these firms tends to be large, and future uncertainty is large. This means that analyst forecasts are not useful for the equity market. This might be one of the reasons that analyst forecasts of firms that depend largely on bank loans are less incorporated into the market value of equity.

With respect to other variables, the coefficient of $A F$ is positive and significant. This indicates that analyst forecasts have value relevance. The result is consistent with Dechow et al. (1999) and Nara and Noma (2012). The coefficient of $B$ is positive, whereas $E$ is negative. Both, however, are significant to both analyses. 
TABle 6. VAlue ReleVAnce ANalyses

Panel A: Discriptive statistics

\begin{tabular}{lcccccccc}
\hline \hline & MVE & B & E & MF & AF & LOAN & LOAN*MF & LOAN*AF \\
\hline Min. & 0.619 & 0.082 & -0.882 & -0.299 & -0.223 & 0.000 & -0.170 & -0.127 \\
1 st & 0.929 & 0.515 & 0.025 & 0.036 & 0.037 & 0.052 & 0.002 & 0.002 \\
Median & 1.016 & 0.739 & 0.043 & 0.050 & 0.052 & 0.189 & 0.007 & 0.007 \\
Mean & 1.049 & 0.808 & 0.034 & 0.051 & 0.053 & 0.233 & 0.013 & 0.013 \\
3rd & 1.138 & 1.020 & 0.061 & 0.066 & 0.068 & 0.373 & 0.019 & 0.019 \\
Max. & 2.185 & 2.792 & 0.210 & 0.207 & 0.187 & 0.920 & 0.150 & 0.147 \\
\hline
\end{tabular}

Panel B: Correlations

\begin{tabular}{lcccccccc}
\hline \hline & MVE & B & $\mathrm{E}$ & MF & AF & LOAN & LOAN*MF & LOAN*AF \\
\hline MVE & 1.000 & & & & & & & \\
B & 0.293 & 1.000 & & & & & & \\
$\mathrm{E}$ & -0.112 & -0.161 & 1.000 & & & & & \\
MF & 0.135 & 0.006 & 0.452 & 1.000 & & & & \\
AF & 0.098 & -0.032 & 0.525 & 0.959 & 1.000 & & & \\
LOAN & 0.087 & -0.036 & -0.109 & 0.107 & 0.092 & 1.000 & & \\
LOAN*MF & 0.114 & -0.014 & 0.206 & 0.671 & 0.635 & 0.673 & 1.000 & \\
LOAN*AF & 0.090 & -0.033 & 0.258 & 0.652 & 0.664 & 0.672 & 0.979 & 1.000 \\
\hline
\end{tabular}

Panel C: Regression results: Management forecasts

\begin{tabular}{|c|c|c|c|c|c|c|c|c|c|c|}
\hline & \multicolumn{4}{|c|}{ [1] OLS analysis } & \multicolumn{3}{|c|}{ [2] OLS analysis } & \multicolumn{3}{|c|}{$\begin{array}{c}\text { [3] clustered-standard error } \\
\text { regression }\end{array}$} \\
\hline & Estimate & $\mathrm{t}$ value & & VIF & Estimate & $t$ value & & Estimate & $\mathrm{t}$ value & \\
\hline (Intercept) & 0.936 & 68.446 & **** & & 0.860 & 79.823 & *** & 0.860 & 21.490 & **** \\
\hline B & 0.087 & 11.646 & $* * *$ & 1.462 & 0.144 & 21.091 & $* * *$ & 0.144 & 2.400 & $* *$ \\
\hline E & -0.315 & -5.988 & $* * *$ & 1.424 & -0.377 & -8.893 & $* * *$ & -0.377 & -3.960 & *** \\
\hline MF & 1.709 & 8.641 & $* * *$ & 3.547 & 1.470 & 10.628 & $* * *$ & 1.470 & 2.000 & $* *$ \\
\hline MF*LOAN & -1.193 & -2.547 & $* *$ & 5.824 & -1.123 & -3.350 & $* * *$ & -1.123 & -3.010 & *** \\
\hline LOAN & 0.114 & 3.947 & $* * *$ & 3.529 & 0.144 & 6.219 & $* * *$ & 0.144 & 2.820 & $* * *$ \\
\hline year dummy & Yes & & & & \multicolumn{3}{|c|}{ No } & \multicolumn{3}{|c|}{ NA } \\
\hline industry dummy & Yes & & & & \multicolumn{3}{|c|}{ Yes } & \multicolumn{3}{|c|}{ Yes } \\
\hline adj. $R^{2}$ & 0.401 & & & & \multicolumn{3}{|c|}{0.146} & \multicolumn{3}{|c|}{0.146} \\
\hline $\mathrm{R}^{2}$ & 0.407 & & & & \multicolumn{3}{|c|}{0.152} & \multicolumn{3}{|c|}{0.152} \\
\hline
\end{tabular}


TABLE 6. (continued)

Panel D: Regression results: Analyst forecasts

\begin{tabular}{|c|c|c|c|c|c|c|c|c|c|}
\hline & \multicolumn{4}{|c|}{ [1] OLS analysis } & \multicolumn{2}{|c|}{ [2] OLS analysis } & \multicolumn{3}{|c|}{$\begin{array}{c}\text { [3] clustered-standard error } \\
\text { regression }\end{array}$} \\
\hline & Estimate & $\mathrm{t}$ value & & VIF & Estimate & $\mathrm{t}$ value & Estimate & $\mathrm{t}$ value & \\
\hline (Intercept) & 0.931 & 71.153 & $* * *$ & & 0.857 & $78.364^{* * *}$ & 0.857 & 21.080 & $* * *$ \\
\hline B & 0.091 & 12.255 & $* * *$ & 1.461 & 0.147 & $21.615^{* * *}$ & 0.147 & 2.510 & $* *$ \\
\hline $\mathrm{E}$ & -0.364 & -6.588 & $* * *$ & 1.541 & -0.395 & $-8.894^{* * *}$ & -0.395 & -3.580 & $* * *$ \\
\hline $\mathrm{AF}$ & 1.793 & 10.389 & $* * *$ & 3.698 & 1.454 & $10.455^{* * *}$ & 1.454 & 2.040 & $* *$ \\
\hline AF*LOAN & -1.334 & -3.142 & $* * *$ & 5.844 & -1.297 & $-3.857^{* * *}$ & -1.297 & -4.000 & *** \\
\hline LOAN & 0.123 & 4.499 & $* * *$ & 3.607 & 0.158 & $6.727^{* * *}$ & 0.158 & 3.040 & $* * *$ \\
\hline year dummy & Yes & & & & \multicolumn{2}{|c|}{ No } & \multicolumn{3}{|c|}{ NA } \\
\hline industry dummy & Yes & & & & \multicolumn{2}{|c|}{ Yes } & \multicolumn{3}{|c|}{ Yes } \\
\hline $\begin{array}{r}\text { adj. } \mathrm{R}^{2} \\
\end{array}$ & 0.401 & & & & \multicolumn{2}{|c|}{0.141} & \multicolumn{3}{|c|}{0.141} \\
\hline $\mathrm{R}^{2}$ & 0.407 & & & & \multicolumn{2}{|c|}{0.148} & \multicolumn{3}{|c|}{0.148} \\
\hline
\end{tabular}

Note: Table 6 shows the results of the value relevance analysis regarding equations (10) and (11). The sample includes 4,681 firm-year observations that were listed on the Japanese equity market from 2001 to 2011.

$$
\begin{gathered}
M V E_{t}=\alpha_{0}+\alpha_{1} B_{t-1}+\alpha_{2} E_{t-1}+\alpha_{3} M F_{t}+\alpha_{4}\left(M F_{t} \times L_{L A N}\right)+\alpha_{5} L O A N_{t} \\
+\sum_{t=2}^{T} \gamma_{t} Y D_{t}+\sum_{j=2}^{J} \delta_{j} I D_{j}+\varepsilon_{t} . \\
M V E_{t}=\alpha_{0}+\alpha_{1} B_{t-1}+\alpha_{2} E_{t-1}+\alpha_{3} A F_{t}+\alpha_{4}\left(A F_{t} \times L O A N_{t}\right)+\alpha_{5} L O A N_{t} \\
+\sum_{t=2}^{T} \gamma_{t} Y D_{t}+\sum_{j=2}^{J} \delta_{j} I D_{j}+\varepsilon_{t} .
\end{gathered}
$$

where $M V E$ is the market value of equity as of the end of the fiscal year, $B$ is the book value of equity, $E$ is the net income, $M F$ is the management forecast, $L O A N$ is the weight of bank loan to external financing, $A F$ is the analyst forecasts, $Y D$ is the year dummy, $I D$ is the industry dummy. All variables except $L O A N$ and dummy variables are divided by the $M V E_{t-1}$ for the purpose of size adjustment. [1] is the result of OLS analysis applying White's standard error. [2] is the result of OLS without year dummy analysis applying White's standard error. [3] is the result of the clustered-standard error regression using standard errors clustered at the firm and year level. ${ }^{* * *}$ indicates significance at the $1 \%$ level. ${ }^{* *}$ indicates significance at the $5 \%$ level.

\section{Conclusion}

This paper investigates whether and how the dependence on bank loans affects management and analyst forecasts in Japan, where indirect finance has played an important role in financial arrangements. We study 4,681 firm-year observations listed in the Japanese equity market from 2001 to 2011. We conduct three analyses and obtain the following results. First, dependence on bank loans increases management forecast errors. Second, dependence on bank loans increases 
analyst forecast errors and dispersion but has little to do with analyst coverage. Third, dependence on bank loans decreases the value relevance of management and analyst forecasts.

These empirical results show that management forecasts of firms that depend on bank loans are not accurate. Because there is not a sufficiently strong incentive for managers to disclose, they are not keen to assign resources to constructing management forecasts. We believe that investors do not require public information, because they can easily rely on bank monitoring. Furthermore, the cost of public disclosure is expensive, compared to private information provided to a few banks. The empirical results pertaining to analyst forecasts indicate that information environment is insufficient. We believe that there is no strong demand for analysts' in-depth research by investors. Because investors do not need to closely examine firms that depend on bank loans, the stock prices do not fully incorporate that information.

Our empirical result has two limitations. First, our empirical result does not consider the possibility of reverse causality. There is potential that poor disclosure prevents a rise in the capital market. The other is the endogeneity problem. There may be a fundamental characteristic of firms that affects the level of the weight of bank-loan dependence and management forecasts.

\section{REFERENCES}

Baginski, S. P., and J. M. Hassell. 1990. The Market interpretation of management earnings forecasts as a predictor of subsequent financial analyst forecast revision. The Accounting Review 65 (1): 175-190.

Baker, M., and J. Wurgler. 2002. Market timing and capital structure. Journal of Finance 57 (1): 1-32.

Bank of Japan. 2003. International comparison of flow of funds accounts. Available at: https://www.boj.or.jp/research/brp/ron_2003/data/ron0312a.pdf (last accessed August 7, 2013).

Barron, O. E., and P. S. Stuerke. 1998. Dispersion in analysts' earnings forecasts as a measure of uncertainty. Journal of Accounting, Auditing and Finance 13 (3): 245-270.

Bhushan, R. 1989. Firm characteristics and analyst following. Journal of Accounting and Economics $11(2-3):$ 255-274.

Brown, L. 1997. Analyst forecasting errors: Additional evidence. Financial Analysts Journal 53 (6): 81-88.

Chen, Q. and R. Vashishtha. 2017. The effects of bank mergers on corporate information disclosure. Journal of Accounting and Economics 64 (1): 56-77.

Cheong, C. S., and M. A. Masum. 2010. Financial analysts' forecast accuracy: Before and after the introduction of AIFRS. Australasian Accounting Business and Finance Journal 4 (3): 65-81.

Choi, J., and D. Ziebart. 2004. Management earnings forecasts and the market's reaction to predicted bias in the forecast. Asia Pacific Journal of Accounting and Economics 11 (2): 167-192.

Dass, N., and M. Massa. 2011. The impact of a strong bank-firm relationship on the borrowing firm. The Review of Financial Studies 24 (4): 1204-1260.

Dechow, P. M., A. P. Hutton, and R. G. Sloan. 1999. An empirical assessment of the residual income valuation model. Journal of Accounting and Economics 26 (1-3): 1-34. 
Diamond, D. 1984. Financial intermediation and delegated monitoring. The Review of Economic Studies 51 (3): 393-414.

Eng, L. L., and Y. T. Mak. 2003. Corporate governance and voluntary disclosure. Journal of Accounting and Public Policy 22 (4): 325-345.

Fama, E. F. 1985. What's different about banks? Journal of Monetary Economics 15 (1): 29-39.

Frankel, R., M. McNichols, and P. Wilson. 1995. Discretionary disclosure and external financing. The Accounting Review 70 (1): 135-150.

Hayes, R. 1998. The impact of trading commission incentives on analysts' stock coverage decisions and earnings forecasts. Journal of Accounting Research 36 (2): 299-320.

Healy, P., A. Hutton, and K. Palepu. 1999. Stock performance and intermediation changes surrounding sustained increases in disclosure. Contemporary Accounting Research 16 (3): 485-520.

Healy, P., and K. Palepu. 2001. Information asymmetry, corporate disclosure, and the capital markets: A review of the empirical disclosure literature. Journal of Accounting and Economics 31 (1-3): 405-440.

Hoshi, T., A. Kashyap, and D. Scharfstein. 1990. Asymmetric Information, Corporate Finance, and Investment. Chicago, IL: University of Chicago Press.

Irani, A. 2000. Determinants of bias in management earnings forecasts. Accounting Enquiries 10 (1): 33-86.

Jaggi, B. 1980. Further evidence on the accuracy of management forecasts vis-a-vis analysts' forecasts. The Accounting Review 55 (1): 96-101.

Japan Exchange Group. 2016. Share distribution survey. Available at: https://www.jpx.co.jp/markets/statistics-equities/examination/01.html (last accessed May 9, 2017).

Jensen, M. C., and W. H. Meckling. 1976. Theory of the firm: Managerial behavior, agency costs and ownership structure. Journal of Financial Economics 3 (4): 305-360.

Koga, K., and S. Uchino. 2012. Bank-firm relationships and security analyst activities: Evidence from Japan. The Japanese Accounting Review 2: 49-73.

Lang, M., and R. Lundholm. 1993. Cross-sectional determinants of analysts' ratings of corporate disclosures. Journal of Accounting Research 31 (2): 246-271.

Lang, M., and R. Lundholm. 1996. Corporate disclosure policy and analyst behavior. The Accounting Review 71 (4): 467-492.

Lang, M., and R. Lundholm. 2000. Voluntary disclosure and equity offerings: Reducing information asymmetry or hyping the stock? Contemporary Accounting Research 17 (4): 623-662.

Leftwich, R. 1983. Accounting Information in private markets: evidence from private lending agreements. The Accounting Review 58 (1): 23-42.

Lo, A. K. 2014. Do declines in bank health affect borrowers' voluntary disclosures? Evidence from international propagation of banking shocks. Journal of Accounting Research 52 (2): 541-581.

McLaughlin, R., A. Safieddine, and G. K. Vasudevan. 1998. The information content of corporate offerings of seasoned securities: An empirical analysis. Financial Management 27 (2): 31-45. 
Ministry of Finance. 2014. Survey of corporations. Available at:

https://www.e-stat.go.jp/stat-search/files?page $=1 \&$ layout=datalist\&toukei $=00350600 \&$ tstat $=$ $000001047744 \&$ cycle $=8 \&$ year $=20131 \&$ month $=0 \&$ tclass $1=000001047749 \&$ file_type $=0 \&$ res ult_back=1\&second2 $=1$ (last accessed October 1, 2014).

Nara, S., and M. Noma. 2012. Forecast accuracy and value relevance by firm size -In comparison of management forecast and analyst forecast. Working Paper. Hitotsubashi University.

Ohlson, J. 2001. Earnings, book values and dividends in equity valuation: An empirical perspective. Contemporary Accounting Research 18 (1): 107-120.

Ota, K. 2006. Determinants of bias in management earnings forecasts: Empirical evidence from Japan. In N. Gregoriou, and M. Gaber (Eds.), International Accounting: Standards, Regulations, and Financial Reporting (pp. 267-294). Burlington, MN: Elsevier Press.

Petersen, M. A., and R. G. Rajan. 1994. The benefits of lending relationships: Evidence from small business data. The Journal of Finance 49 (1): 3-37.

Richardson, V. R. 2000. Information asymmetry and earnings management: Some evidence. Review of Quantitative Finance and Accounting 15 (4): 325-347.

Rock, S., S. Sedo, and M. Willenborg. 2000. Analyst following and count-data econometrics. Journal of Accounting and Economics 30 (3): 351-373.

Vashishtha, R. 2014. The role of bank monitoring in borrowers' discretionary disclosure: Evidence from covenant violations. Journal of Accounting and Economics 57 (2-3): 176-195.

Williams, P. 1996. The relation between a prior earnings forecast by management and analyst response to a current management forecast. The Accounting Review 71 (1): 103-115. 